\title{
Anaerobic Digestion Process for the Treatment of High Brix Distillery Spent Wash
}

\author{
Govind P. Misale ${ }^{1^{*}}$, S.E. Neelgund ${ }^{2}$, Vijendra Singh ${ }^{3}$ and S.V. Patil ${ }^{4}$ \\ ${ }^{1}$ Associate Vice President (Ethanol), Renuka Sugars Limited, Belagavi, Karnataka, India \\ ${ }^{2}$ Department of Biochemistry, Kuvempu University, Shimoga, Karnataka, India \\ ${ }^{3}$ Executive Director, Shree Renuka Sugars Limited, Mumbai, Maharashtra, India \\ ${ }^{4}$ Head Alcohol Technology, Vasant Dada Sugar Institute, Pune, Maharashtra, India
}

*Corresponding author: govind.misale@renukasugars.com

Received: $17-07-2019$

Revised: $11-10-2019$

Accepted: $27-11-2019$

\begin{abstract}
Distillery spent wash is the unwanted residual liquid waste generated during alcohol production and the pollution caused by it has become a critical environmental issue. Despite standards imposed on effluent quality, untreated or partially treated effluent very often finds access to watercourses. The distillery wastewater with its characteristic unpleasant odour poses a serious threat to the water quality in several regions around the globe. In this study, experiments were carried out to investigate the production of biogas from distillery spent wash by using an anaerobic digestion process with Continuous Stirred Tank Reactor (CSTR). The experiment was carried out to calculate the efficiency of the production of biogas. The digester was operated with feed of high Brix Spentwash. The digester shows stable performance with production of biogas.
\end{abstract}

Keywords: Anaerobic Digestion, Spent Wash, Alcohol Production.

Distillery spent wash refers to the effluent generated from alcohol distilleries. On an average, 8-15 L of effluent is generated for every litre of alcohol produced. The alcohol distilleries are extensively growing due to widespread industrial applications of alcohol such as in pharmaceuticals, food, perfumery, etc. It is also used as an alternate fuel. There are 319 distilleries in India alone, producing 3.25 billion litres of alcohol and generating 40.4 billion litres of wastewaters annually. As per the Ministry of Environment and Forests (MoEF), alcohol distilleries are listed at the top in the "Red Category" industries. Alcohol production in distilleries consists of four main steps viz. feed preparation, fermentation, distillation, and packaging. Ethanol can be prepared from various biomass materials but the potential for their use as feedstock depends on the cost, availability, carbohydrate contents, and the ease by which they can be converted to alcohol. Nearly $61 \%$ of world's ethanol production is from sugar crops. Most Indian distilleries exclusively use cane molasses as raw material for fermentation. Ethanol accumulates up to $8-10 \%$ in the fermented mash. The fermented mash is then distilled, fractionated and rectified after the removal of yeast (e.g., Saccharomyces cerevisiae) or bacterial (e.g., Zymomonas mobilis) sludge. The residue of the fermented mash which comes out as liquid waste is termed as spent wash. The main objective of this study was to treat the distillery spent wash using an anaerobic process for biogas production and to characterize the spent wash for various parameters such as COD, BOD, pH etc. To study the effect of 
organic loading on the performance of anaerobic digestion process and to find the amount of biogas produced.

\section{MATERIALS AND METHODOLOGY}

\section{Anaerobic digestion (stages)}

Biogas production through anaerobic digestion is a biochemical process involving conversion of complex biological and organic wastes in sequential stages into Methane, the major energy fuel.

Stage 1: The hydrolytic bacteria primarily are involved in the breakdown of complex organic waste streams into simple sugars, fats \& oils, and amino acids. This stage involves splitting of the complex organic biological molecules into simpler forms, the process is known as Hydrolysis or Liquefaction.

Stage 2: The Fermentative acidogenic bacteria convert the hydrolysed portion into organic acids.

Stage 3: The Fermentative acidogenic bacteria then convert the organic acids into hydrogen, acetate and carbon dioxide $\mathrm{CO}_{2}$.

Stage 4: Finally the methane producing bacteria, the methanogens, simultaneously produce biogas from the acetate, or from hydrogen \& carbon dioxide.

\section{Sources of Waste Water}

Process Waste Streams: Spent wash from Analyser Column Fig. 1.

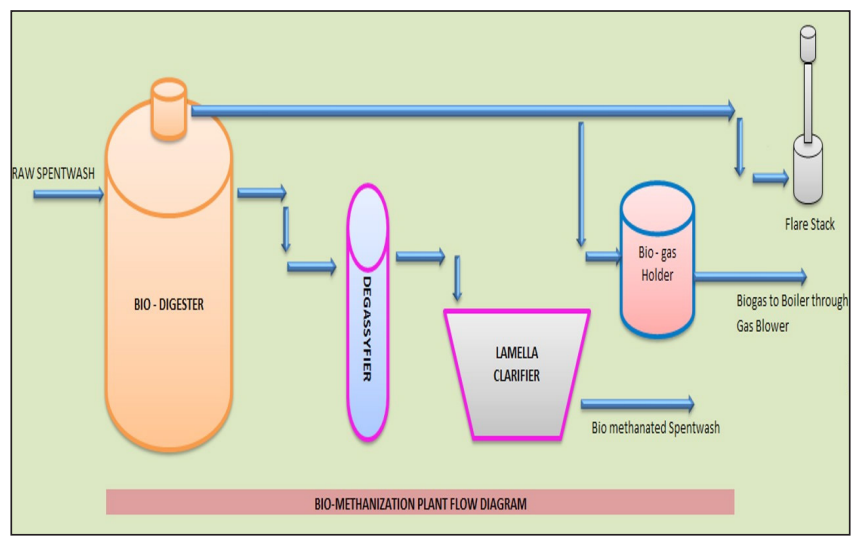

Fig. 1: Bio-Methanization Plant flow chart

\section{Experimental Setup}

Tank of capacity $15 \mathrm{M} 3$ has been used as digester with working volume of $12.5 \mathrm{M} 3$. The schematic diagram of the experimental setup for this study is shown in Fig. 2.

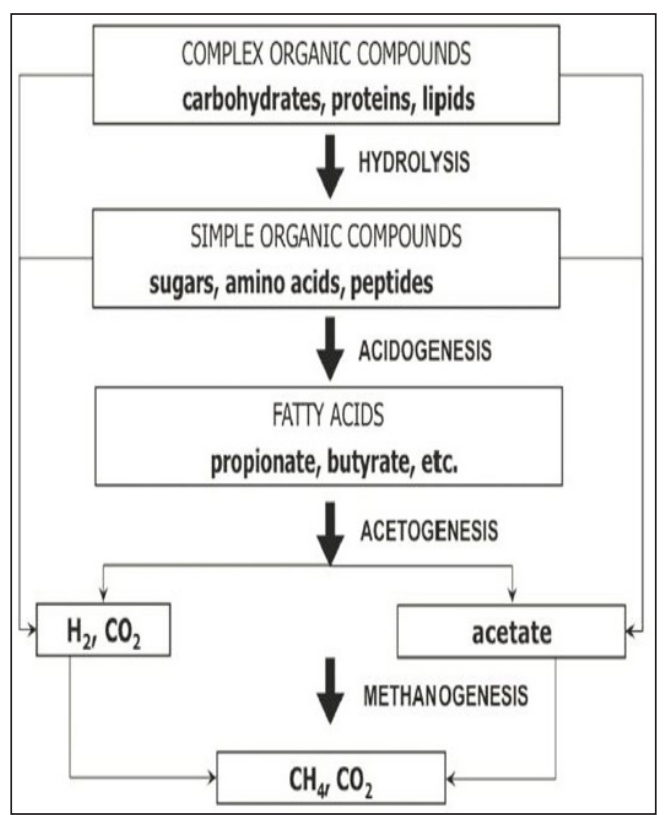

Fig. 2: Formation of Methane from Complex Organic compounds

The organic loading rate was calculated based upon the working volume of the digester.

\section{General Characteristics of Distillery Effluent}

The fresh Spentwash from the analyser bottom has been used. The key pollutants in this spent wash are organic compounds and solids. The BOD is $65000 \mathrm{mg} / \mathrm{l}$ and COD is $160000 \mathrm{mg} / \mathrm{l}$ and total suspended solids $1000 \mathrm{mg} / \mathrm{l}$. The $\mathrm{pH}$ value in this case varies from 3.8 to 4.4. When waste water contains high concentration of organic matter, in absence of oxygen, sulphate acts as an electron acceptor to produce $\mathrm{H}_{2} \mathrm{~S}$ and odour.

\section{Start-up of Reactor}

During the start-up of reactor, the reactor was loaded with 150 litre of isolated anaerobic organism culture and 1000 litre of spent wash (6-7 Brix) with a COD concentration of $40000 \mathrm{mg} / \mathrm{l}, \mathrm{pH} 7.0$ \& temp. $37{ }^{\circ} \mathrm{C}$ 
was loaded along with micro nutrients of specified dosage. Later on daily reactor was feed with 800 litre Spentwash with increasing Brix. Once reactor gets level then feed maintained per day 250 lit. The reactor was loaded with continuously increasing brix and operated for a period of 30 days untill it attains stabilization. During this period $\mathrm{pH}$ is maintained from 7.2 to 7.6 and temperature is maintained from 37 to $39{ }^{\circ} \mathrm{C}$. During various organic loading, effluent samples was collected for analysis of various parameters such as $\mathrm{pH}, \mathrm{BOD}, \mathrm{COD}$, alkalinity etc.

\section{RESULTS AND DISCUSSION}

The anaerobic digestion is suitable particularly for distillery wastewater. TheCOD/N/Pratiofor anaerobic digestion could be in the order of 800/5/1. The main parameters used for the characterisation of anaerobic digestion are: input and output concentrations of COD ( $\mathrm{kg} \mathrm{COD} \mathrm{or} \mathrm{BOD} / \mathrm{m}^{3}$ of wastewater), organic loading rate $\left(\mathrm{kg} \mathrm{COD} / \mathrm{m}^{3}\right.$ of digester/d), hydraulic retention time (day), gas productivity ( $\mathrm{m}^{3}$ of biogas/ $\mathrm{m}^{3}$ of digester $/ \mathrm{d}$ ), methane production $\left(\mathrm{m}^{3}\right.$ biogas $/ \mathrm{kg}$ COD removed) and COD (or BOD) removal efficiency (COD removed/COD applied). The organic load depends on the technology used and on the type of wastewater to be treated. The organic load obtained with suspended microorganism technologies is between 1 to $5 \mathrm{~kg} \mathrm{COD} / \mathrm{m}^{3} / \mathrm{d}$. With UASB reactors, the load applied is between $5 \mathrm{~kg}$ to $15 \mathrm{~kg} \mathrm{COD} / \mathrm{m}^{3} / \mathrm{d}$. For anaerobic filters it is between $5 \mathrm{~kg}$ to $20 \mathrm{~kg}$ COD/ $\mathrm{m}^{3} / \mathrm{d}$ and generally between $15 \mathrm{~kg}$ to $30 \mathrm{~kg} \mathrm{COD} / \mathrm{m}^{3} / \mathrm{d}$ for the fluidised bed. The COD removal yields are generally high for distillery wastewater treatment. The values are generally between $80-98 \%$. The biogas production is around 500 to 600 litres per $\mathrm{kg}$ of COD removed with $60-80 \%$ methane. The organic flow should be adjusted to the reaction capacity of the micro-organisms. If the reactor is overloaded, volatile fatty acids will accumulate, $\mathrm{pH}$ will fall down and we have a failure of the anaerobic reactor. Even with high depollution yields, anaerobic digestion treatment is generally not enough to release the effluent in natural environment. Therefore anaerobic digestion is generally followed by an aerobic treatment. Anaerobic digestion of spent wash in a closed digester followed by its treatment under an activated sludge process, especially in an oxidation ditch to reduce costs, might be adopted as the most cost-effective system for the distilleries which are located away from sugar factories.

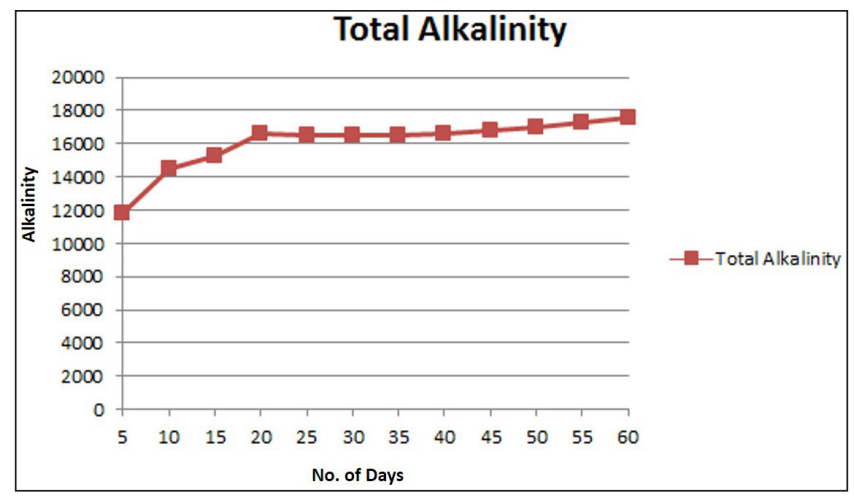

Fig. 3: Graph of Total Alkalinity

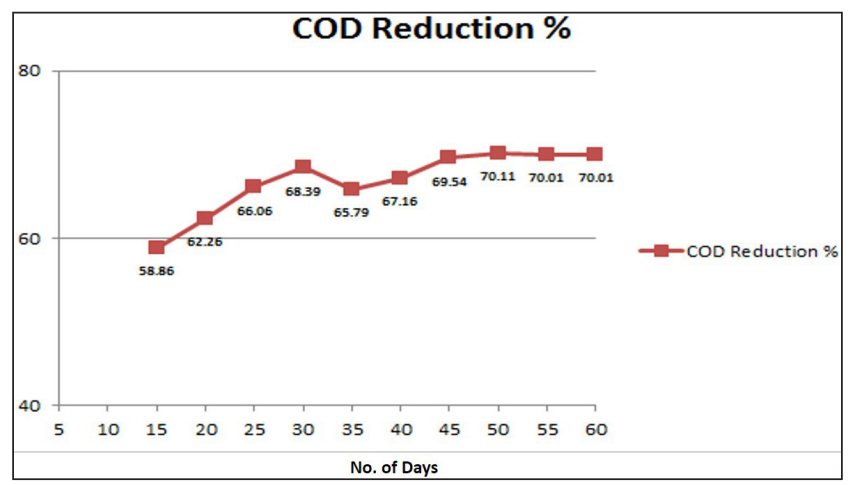

Fig. 4: Graph of percent COD reduction

The results of alkalinity, percentage (Fig. 3) of COD removal (Fig. 4) and Gas removal are shown in (Fig. 5). The reactor was started with $6^{0}$ Brix with COD $40000 \mathrm{mg} / \mathrm{l}$. Daily feeding given with increasing brix. 30 days required to get stabilise the digester. During this alkalinity increased from $5700 \mathrm{mg} / 1$ to 15000 $\mathrm{mg} / \mathrm{l}$. Maximum COD reduction observed on $45^{\text {th }}$ day. As time increased COD reduction increased \& get stabilise \& accordingly gas production also get stabilise. The reactor was started with an OLR of 0.5 $\mathrm{kg} \mathrm{COD} / \mathrm{m}^{3} . \mathrm{d}$ and operated for a period of 30 days till it attains stabilization. During this period the $\mathrm{pH}$ is maintained from 7.02-7.04. The alkalinity increased 
from $1080-2980 \mathrm{mg} / \mathrm{L} \&$ and COD reduced from $4200-$ $3000 \mathrm{mg} / \mathrm{L}$, refer Fig. 3 . On $30^{\text {th }}$ day the maximum COD removal efficiency obtained is $79.72 \%$ \& gas produced is $451 \mathrm{~mL}$. As the time increased, \%COD removal increased \& attained optimum value on 30th day. When the OLR was increased from 0.5 to 1.0 $\mathrm{kg} C O D / \mathrm{m}^{3} \cdot \mathrm{d}\left(35-60^{\text {th }}\right.$ day) \& operated for a period of 25days till it attains stabilization. Throughout the study period the $\mathrm{pH}$ is maintained from 7.107.03, the alkalinity increased from 810- $1945 \mathrm{mg} / \mathrm{L}$ \& COD reduced from $5270-4248 \mathrm{mg} / \mathrm{L}$, refer Fig. 4. On 60th day the maximum COD removal efficiency obtained is $71.29 \%$ \& gas produced is $815 \mathrm{~mL}$. As the time increased, \%COD removal increased \& attained optimum value on $60^{\text {th }}$ day. When the OLR was increased from 1.0 to $1.5 \mathrm{~kg} \mathrm{COD} / \mathrm{m}^{3} . \mathrm{d}\left(60-88^{\text {th }}\right.$ day) \& operated for a period of 28 days till the reactor stabilises.

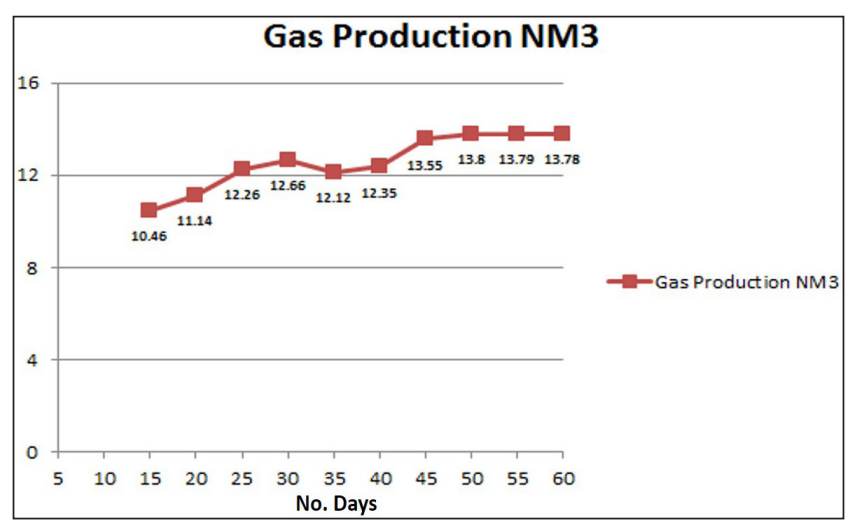

Fig. 5: Graph of Gas Production

Throughout the study period the $\mathrm{pH}$ is maintained from 7.02-7.08, the alkalinity increased from 690$1110 \mathrm{mg} / \mathrm{L}$ \& COD reduced from 6370-5470 mg/L refer Fig. 5. On $88^{\text {th }}$ day the maximum COD removal efficiency obtained is $63.04 \%$ \& gas produced is $1150 \mathrm{~mL}$. As the time increased, \%COD removal increased \& attained optimum value on 88th day. Moreover, the treated effluent can be conveniently used for irrigation of cane fields or other crop lands, subsequently. Biogas generated from the distillery effluents, can be effectively utilized in production plant boilers thus saving about 50 to 60 percent fuel/ steam. The treated effluent having almost all the potash Low production of waste biological solids. Low nutrient requirements. Production of methane as an energy source to meet the steam requirement of distillery to the extent of $75-100 \%$. Very high loading rates can be achieved. Active-anaerobic sludge can be preserved unfed for many months. Based on the experimental study it can be concluded that the spent wash is highly organic in nature having high value of COD $(41,100 \mathrm{mg} / \mathrm{L})$. The maximum COD removal efficiency is $79.72 \%$ achieved after $30^{\text {th }}$ day (optimizing time) at an organic loading rate of 0.5 $\mathrm{kg} \mathrm{COD} / \mathrm{m}^{3} . \mathrm{d}$. The maximum biogas produced is $1150 \mathrm{~mL}$ after $88^{\text {th }}$ day of the start of reactor at an OLR of $1.5 \mathrm{~kg} / \mathrm{m}^{3}$.d. It was noticed that the percent COD removal was increased and attained optimum value on 88th day from the start up. As the OLR was increased from 0.5 to $1.5 \mathrm{~kg} \mathrm{COD} / \mathrm{m}^{3}$.d, the volume of gas produced increased form 5-451 mL, 451-815 $\mathrm{mL}$ and $812-1150 \mathrm{~mL}$ respectively, percent COD removal decreased from $71.62-79.72 \%, 64.39-71.29 \%$, $56.95-63.04 \%$ and total alkalinity was decreased from $1080-2980 \mathrm{mg} / \mathrm{L}, 810-1945 \mathrm{mg} / \mathrm{L}$ and $690-1110 \mathrm{mg} / \mathrm{L}$ respectively.

\section{CONCLUSION}

Anaerobic digestion is the most suitable option for the treatment of high strength organic effluents. The present study conclude reviewing the existing anaerobic technological status of treatment and disposal of distillery spentwash in our country. Application of anaerobic digestion to distillery effluents is a preferable primary treatment option. Conversion of COD into biogas through biomethanation appears to be a reasonable solution. The different way of biogas utilisation is the production of steam, electricity, hot water (for small digester capacities) and co-generation. COD plays an important role in biogas production rate. COD reduction goes on increasing as the biogas production rate goes on increasing. The loading rates permissible in an anaerobic waste treatment process are primarily dictated by the sludge retention in an anaerobic reactor. The technologies are simple in construction and operation. 


\section{REFERENCES}

Acharya, B.K., Mohana, S. and Madamwar, D. 2008. Anaerobic treatment of distillery spent wash-A study on upflow anaerobic fixed film bioreactor. Bio-resource Technology, 99(11): 4621-6.

Bernhard Drosg - Process monitoring in biogas plants.

Jain, R. and Srivastava, S. 2012. Nutrient composition of spent wash and its impact on sugarcane growth and biochemical attributes. Physiology and Molecular Biology of Plants, 18(1): 95-9.

Kamble, S.K., Hebbara, M., Manjunatha, M.V., Dasog, G.S. 2016. Influence of long-term irrigation with bio-methanated spentwash on physical and biological properties in a vertisol. Res. Environ. Life Sci., 9(1): 1-3.

Lawrence, A.W. and McCarty, P.L. 1969. "Methane formation in anaerobic treatment", J. Wat. Pollut. Control Fed., 41: R1R7.
Melamane, X., Tandlich, R. and Burgess, J. 2007. Anaerobic digestion of fungally pre-treated wine distillery wastewater. African Journal of Biotechnology, 6(17).

Mohana, S., Acharya, B.K. and Madamwar, D. 2009. Distillery spent wash: treatment technologies and potential applications. Journal of Hazardous Materials, 163(1): 12-25.

Rajendra Lamkhade, Rajani Saranagoudar, Shashikant Mise Treatment of Distillery Spentwash by anaerobic digestion process.

Teodorita Al Seadi, Dominik Rutz, Heinz Prassl, Michael Köttner, Tobias Finsterwalder, Silke Volk, Rainer Janssen Biogas Handbook.

Wolmarans, B. and De Villiers, G.H. 2002. Start-up of a UASB effluent treatment plant on distillery wastewater. Water SA., 28(1): 63-8. 
